\title{
Enhancing Students' Performance in Senior High School Mathematics through the Learner-centered Approach: A Case in T. I. Ahmadiyya Senior High
School, WA, Ghana
}

\author{
Mohammed Subouru Alhassan Bigson, Zulphata Bin Yussif \\ Department of Mathematics, T. I. Ahmadiyya Senior High School, P. O. Box 636, Wa Municipal, Ghana.
}

\begin{abstract}
The study was about enhancing students' performance in mathematics through the learner-centered method of teaching, with T. I. Ahmadiyya Senior High School, Wa as a case study. This led to the formulation of three specific objectives which were; to assess the performance of individual students through written class quizzesbefore and aftertaking lectures and demonstrations on a topic, to assess the performance of students through class quizzes before and aftertaking learning tasks and activities through instructional groups discussions and individual learning, and also to assess the views of teachers and students on both teaching and learning methods.
\end{abstract}

The first 80 students who reported to school to begin the first semester of the 2021 academic year, were selected to form the sample groups: 'Form 1 and Form 2'. After undertaking lessons, the findings which were based on the marks scored by individual students in various class quizzes showed that, students scored higher marks after undertaking lessons through group discussions and that of individual learning activities, but scored lower marks after taking lessons through the lecture and demonstration method of learning. Discussions between the researchersand the respondents (students and teachers)revealed that, the learner-centered method of teaching was most preferred and better to enhance the performance of students, as compared to that of the traditional method (teacher-centered) of imparting knowledge. Even though the traditional method enables larger coverage of study content within a short time, it is a disadvantage to slow learners, but however favours the smart ones. At some point, using the mixed method (both teacher-centered and learner-centered) could enhance better results other than strictly sticking to one method. The study therefore recommended that; similar studies be undertaken in different institution and different subjects of study.

Keywords: Learner-centered, Teacher-centered

\section{INTRODUCTION}

\subsection{Background}

$\mathrm{M}$ athematics education has always been a keen area of relevance in every nation's academic curricular, and therefore any parameter that could enhance its' improvement should not be undermined. These parameters which include stakeholders such as education policy makers, education managements, teachers, and especially learners should play their various roles towards its' improvement.

One of the keen reasons while mathematics education is of relevance, especially in the second cycle institutions is because, it prepares learners to cope with the continuous changing world through logical reasoning, critical thinking and other effective methods of problem identification and solving [1]. Aside enhancing the usual practice of teaching and learning in educational institutions, socio-economic and technological potentials in global market are also realized by learners [2].

In Ghana, mathematics education is compulsory from the first grade up to pre-tertiary level, and the content that runs it in the curricula at all levels are almost comparable to those run by other countries [3].

However, mathematics is seen not only as a difficult subject but also a boring one by most learners, especially when their (learners) participation is insignificant, which therefore results in low understanding and poor performance. Learners' positive attitude in the study of mathematics as well as their performance in the subject could be influenced largely by the method of teaching. In most learning institutions, knowledge is passed on from a teacher (instructor) to learners (students) by the use of teaching and learning materials [4].

The teacher-centered approach, often referred as the 'traditional approach or teacher knows it all' [5], is the approach whereby the teacher submit knowledge to the learners (receivers/listeners). This approach focuses more on what the teacher knows other than the learners' capability of knowing what should be learnt, and therefore learners have to pay serious attention to teachers as they pass knowledge to them.

Numerous researches have alluded that, the learner-centered approach of imparting knowledge is quiet better as compared to the traditional approach [5]. In this approach (learnercentered/student-centered), learners are explicitly focused on their conceptual understanding and collaboration in the learning process, while the teacher facilitate the learning process [6]. Learners exposed to this type of instruction are 
invested with confidence which further enables them to actively participate significantly in the learning process by asking more questions, sharing their own ideas and information they generate out of their own comparison.

\subsection{Statement of the problem}

In Ghana, passing mathematics is key requirement for gaining admission to pursue any kind of program in the higher institution, pursuant to which, most high school graduates have been rejected due to their inability to pass in mathematics and/or in other relevant subjects. Most of these applicants are usually those who possess senior high school certificate as a highest credential, especially the immediate graduates from senior high schools. It is therefore necessary to focus on both teaching and learning approaches that will enhance performance in critical subjects like mathematics at this level (S.H.S).

Although teachers have been trained with educational curricula which recommends the use of learner-centered approach of teaching [7], most teachers still use the traditional teacher-centered approach due to factors such as; covering a large aspect within a short time, inadequate textbooks, and easy approach to introducing new knowledge.

\subsection{Purpose of the study}

The study seeks to enhance students' performance insenior high school mathematics through the use of the learnercentered approach of teaching.

i. To assess the performance of individual learners through written class quizzes before and after taking lectures and demonstrations on a mathematics topic.

ii. To assess the performance of learners through class quizzes before and after taking learning tasks and activities through instructional groups discussions, and individual learning.

iii. To assess the views submitted by teachers and learners, on teaching and learning methods, using qualitative assessment.

\subsection{Research questions}

i. What are the scores obtained by students in various class quizzes before and after taking lectures and demonstrations on a mathematics topic?

ii. What are the scores obtained by students in various quizzes before and after taking small group discussion and individual learning activities on a mathematics topic?

iii. What are the views of teachers and learners on the methods of imparting knowledge?

\section{LITERATURE REVIEW}

This part gives account on background and justification of already existing studies that have been undertaken on the study of mathematics, and the different approaches used in transferring knowledge to learners. It also explores studies which appraised the learner-centered method as a better approach for imparting knowledge to learners.

\subsection{Mathematics Education}

Mathematics either as a course, a module, a subject or a program is seen as a fundamental part for logical reasoning and human thoughts, and a necessity for understanding ourselves and our environment. It is also a significant subject that forms a foundation of other subjects which constitute the curricula of most levels of education (i.e. grade 1 up to grade 12) in most countries worldwide.

According to Mereku, the advancement of information and communication technologies have tremendously increased the usefulness of mathematics and is foreseen to continue to the next generation [7]. There is therefore the need to understand how this advancement together with other developments have evolved the content of the subject as well as emphasis in schools especially, in Ghana.

\subsubsection{Factors affecting learning outcome in Mathematics}

According to Bethel, the importance of mathematics education is reflected in the duration spent in imparting it, which is comparable to those allocated in developed systems [2]. Over the past 2 decades, curricula revision and modernization has been a key issue on educational reforms, with emphasis on moving towards competency and outcomesbased models. In reality, most mathematics curricula in subSaharan Africa are been delivered by teacher-led methodologies, even though there have been more advocacies on learner-centered methods. Bethel however identified factors affecting mathematics learning as; the value attached to the subject by the people, the perception of difficulty placed in the subject, and how learners acquire its' understanding [2].

\subsubsection{Making Mathematics teaching more effective}

According to Karp, we are moving away from the traditional model where a teacher treats the entire class as a unit, to the modern model where learners in single class work relatively independently, or on their own projects in smaller groups [9]. Planning and organizing a lesson should be channelled to practical problem-solving which fully involve learners' participation. And also, technological discoveries could have a great impact on mathematics education irrespective of the changes they made to the content, but technologies have ushered in new methods and resources which enhance students understanding and assessment as well. These and others that enhance effectiveness in teaching mathematics could be discussed in details in a later development.

\subsubsection{In-service training for teachers}

Teacher training is an essential part of educational reforms, especially those that indorse the learner-centered approach, since the approach needs well planned activities and teacher's creativity in organizing and managing learning process.

Educators, educational researchers and policy makers have 
argued that, some teachers, especially those who teach mathematics, lack adequate content knowledge and as result are unable to get to the expected level [10]. The Mathematics Teachers Transformation Institute therefore encouraged teachers to further develop their content knowledge as well as learner-centered pedagogy, to help motivate learners to engage in mathematics learning.

\subsection{Theories of teaching}

A French theorist born in Switzerland by name 'Jean Jacque Rousseau', was the founder and first to introduce the learnercentered theory of education based on the idea that; educators should not start an instruction by insisting on what they wish learners to learn, but should first rather pay attention to their capabilities. However, teachers are the managers of classroom teaching and learning, and therefore should have the capacity of managing the classroom effectively [7]. To enhance this effective management, various models and theories which directs the choice of teaching and learning methods could be considered in the teaching and learning process.

\subsubsection{Factory model}

Fredrick W. Taylor viewed school as factory in which instructions and task are standardized, and increase in productivity ('knowledge' in case school setting) is unchangeably constant [7]. In this case, the teacher seen as the overlord of knowledge, and therefore the learning process is incomplete without the participation of the teacher. The proponent 'Frederick W. Taylor proposed an approach in his book 'The Principles of Scientific Management' which proved to be effective when applied to a business model [11]. Two of the most viewed characteristics of the 'factory model of education' are;

1. Top-down management; as seen in the educational world, whereby teachers have almost no control over what is to be taught, as well as learners have very less input on what they can learn.

2. Lack of innovation; since it embraces the traditional method, 'as the leader says all', there is limited room for concerns, creativity and inventive thoughts which may generate better ways to attain goals. Learners for that matter are restricted to what their teachers demand from them during the learning process.

\subsubsection{Constructivism theory}

According to Hein, "constructivism refers to the idea that learners construct knowledge for themselves" where each of them (learner) or collectively (learners) generate understanding on what is been learnt [12]. This theory emerged in 1978 as an alternative to the factory model which emphasizes on traditional approach of leader knows all [7]. But in accordance with the constructivism theory, we have to pay attention on the learners to think about learning and not lessons to be taught, and also for learners to know that, no knowledge is independent to their experiences [12]. Hein therefore concluded that, the principles of constructivism is influential in classrooms and curricula organization in schools, and could be applied to learning in other settings (i.e. Museums). The principles also side with modern views of imparting knowledge, but however conflicts with traditional practices.

\subsection{Assessment of Learning}

Teachers and/or external agencies use assessment to determine the strengths and weakness of learners during or after a period of study. According to Ernst,learners can be assessed during or after the learning process in diverse forms such as, quizzes, matching cards, and class discussions [13]. For quizzes, more time is spent on marking and at the same time, learners' interest usually lies on their grades scored and not self-improvement, which makes it less effective to use. However, comments stated on grades do encourage learners to analysis their work for correction. Ernst therefore alluded that, self or peer corrected quizzes is most effective since it enables students to gain instant feedback, which could be acted on before formal assessment [13].

\subsection{Empirical literature}

\subsubsection{Student-centered approach}

The learner-centered approach is a method of imparting knowledge which is highly encouraged in education [14], which encourages learners to be more active in classroom activities to enhance effective learning [15].

Mensah and Attah-Boisonstated on a module in title, 'General Methods, Techniques and Skills in Teaching' that, learnercentered method of teaching is basically the approach whereby learners are more active in the learning process than the teacher or instructor [16]. Learners (students) are therefore placed at the center of the learning process, with emphasis on how they will develop to be well matured thinkers.

Barraket (2005) defined learner-centered approach as the method of obtaining knowledge whereby learners are the key initiators and architects of the learning and knowledge making, and not empty 'vessels' waiting to receive knowledge from transmitters (teachers) [17].

\subsubsection{Group discussion}

Learners in a group undertaking learning activities on their own or with the supervision of a teacher or instructor could be referred as group discussion. Group discussion facilitated by a teacher should be learner-centered [18]. A study conducted by Pijls and Dekker in 2011 with a purpose adding up to existing knowledge on learners group discussions in mathematics [19]. After assigning three teachers to supervise three different groups of learners to undertake group discussions in secondary educational mathematics, it was discovered that, teacher follow-ups during learners group discussions promotes understanding and performance. 
According to a pilot project by Bose and Jehan which assessed the improvement of knowledge, communication skills, and self confidence among learners put in various groups, the outcomes of various post tests and separate tests revealed that; group discussion is significantly helpful in improving communication skills, self-confidence and high performance of learners [18].

\subsubsection{Individualized learning}

When one is required or instructed to tackle things such as; learning, working, on his/her own, it could be referred as individualized learning. According to Mensah and AttahBoison, individualized learning provides learners the free range to pursue their own learning at their own style [16]. With this, learners do not necessarily undertake the same thing and/or at the same time and speed.

According to AgwuUdu's study on 'Comparative Effects of Individual and Cooperative learning', through the use of quasi-experimental design and hypothesis testing, individualized learning and comparative learning enhance better academic performances as compared to traditional methods such as lecture method [20].

\subsubsection{Teacher-centered approach}

The situation whereby a teacher takes a central role in the teaching and learning process is simply referred to as 'teachercentered' method of imparting knowledge [16]. In this situation, the teacher takes full control of the learning process and therefore dictates what is to be learned, and how it would be learned. The learners therefore pay attention to what s/he says or directs them on what to do.

Mensah and Attah-Boison holds further that the lecture method is one of the most common activities of the teachercentered method used to cover large amount of knowledge in a systematic way [16]. As confirmed by the findings of Abdulbaki et al in 'The impact of lecture method on teaching English at university' most learners are able to cover a lot of knowledge from the lecture material, even though their participation in the class was minimal [21]. It therefore implies that, high school learners could face great challenges if taken through lessons using this method of teaching.

Demonstration method of teaching is the teaching procedure whereby the teacher serves as an actor while the learners watch the visual actions in other to act later [22]. Most teachers see this method to be suitable for subjects that possesses physical skills which may include: Physical education, theatre arts, vocational skills and science [16].

\subsubsection{Teachers' and Students' perspective on teaching methods}

Teachers and learners have expressed several concerns about the two approaches of imparting knowledge. Learners are seen as primary customers of education, and teachers are also seen as knowledge providers who have to take into accounts the necessities of their customers [23]. According to Baeten et al, teachers may prefer the traditional methods if they do not want to take active or difficult role in the learning process [23], while learners may also prefer either approach at to their convenience. By the use of questionnaires for both teachers and learners in other to understand instructional preference of teachers and learners towards learning, it was discovered that both parties largely prefer learners-centered approaches but with sufficient amount of guidance and supervision from the teacher [23]. This therefore implies that the collaboration of both actors (teachers and learners) is key in the learning process.

\subsection{Conceptual Framework}

The conceptual framework is an illustration in a map form which displays the variables and actions required to undertake the study. The framework displays the dependent and independent variables, and the kind of relationship to that exist between the throughout the entire study. The independent variables are the performances of the learners which includes; scoring above $50 \%$ of the total mark of the assessment. However, those activities that enable the learners to do well the learning process which includes; brainstorming, focus group discussion and individualized learning are the dependent variables, since the good performance largely depends on those activities.



Fig. 1 Conceptual Framework

Source: Created by researchers, 2021.

\section{RESEARCH DESIGN}

The design of the research is conditioned by the basic features of the study, which includes the study questions, the information needed for the study, and how to possibly acquire that information to respond to the questions posed. 


\subsection{Accessible population}

Accessible population is the total number of defined classes of people, places, objects, and/or events that are realistically considered by the researcher to pick a sample from, which is relevant to the research questions [24]. The accessible study area, T. I. Ahmadiyya senior high school (Unique Amass), is located in the North-Western part of the Wa Municipality, was established in the year 2001 by the Ahmadiyya Muslims Mission of Ghana, purposely to help expand secondary education in the region and the country at large. It has a mixed (male and female) student population of about 1,113, and a teaching staff of about 65 with which 8 of them are mathematics teachers.

\subsection{Sample Size}

The sample is a smaller part of the total population that is of interest to the topic understudy [25]. A sample is usually considered due to difficulty for researchers to acquire information from the whole or target population. However, sample size is the number of units selected from population to form a sample [7]. Since the research is both qualitative and quantitative in nature, the study then considered respondents that can be managed due to the available resources such as time, transportation and stationery.

Below is a table showing the sample population of the study.

TABLE I: Sample population

\begin{tabular}{|c|c|}
\hline Types of respondents & Number of respondents \\
\hline Mathematics teachers & 6 \\
\hline Form 1 students & 45 \\
\hline Form 2 students & 35 \\
\hline
\end{tabular}

Source: Research data from field, 2021.

\subsection{Sampling Procedure}

According to Singh and Masuku, sampling is regarded as the selection of individuals or items (subset) from a population to represent the characteristics of the entire population [26]. There are two main categories of sampling procedures, which are; probability and non-probability sampling [27]. The probability type of sampling is the one in which every item has an equal chance of being selected to be a part of the sample, which can be determined [24]. Out of the first 100 students who reported to school on the reopening day, 45 of them were in Form 1, and 35 of them were in Form 2. The rest of them were in Form 3 but were not included in the study due to their preparation for their 'Mock Examination'. 80 students were therefore considered for the study. The non-probability sampling is the type of sampling which involves non-random (bias) selection based on ease or allowing the researcher to easily collect data [28]. With the purposive sampling, items in the population has no equal chance of been selected to form a sample, and therefore cannot be estimated. Out of over 65 teachers in the school, 8 of them are mathematics teachers, and out of the 8 mathematics teachers, 6 of them are permanent mathematics teachers while the other 2 are temporal. It was on this premise that; the 6 teachers were selected to respond to the study.

\subsection{Data Collection Methods}

These are simply referred as the techniques and tools that are used in acquiring information. Methods used includes; focus group discussions, interviews, observation, documentary review, and class quiz.

\subsubsection{Interview}

An interview is a conversation that is undertaken verbally, with objective of collecting information that is relevant to the purpose of the study [24]. Interviews usually creates a wider chance to explore the experiences of participants. According to Amoah \&Eshun, interviews can be structured, semistructured and unstructured, depending on how the content and procedures involved are prescribed and standardized in advance [24]. In other to give a wider range for participants to share their experiences deeply, through storytelling, the unstructured interviews were used to collect information from respondents.

\subsubsection{Documentary Review}

This method of data collection involves gathering information from secondary sources which includes relevant documents [29], such as exam report, lesson plan, syllabus, and attendance register. The mathematics syllabus was reviewed to select two topics that were to be treated in each of Form 1 and Form 2.

\subsubsection{Focus Group Discussion}

According to HERD, focus group discussion is the situation whereby people of similar backgrounds or experiences group up and undertake a discussion on a specific topic of interest [30]. It is frequently used in most qualitative research in order to gain an in-depth knowledge and understanding of issues related to our social settings [31]. Only the students were engaged in this method, in other to give chance for them to share their collective experiences so freely.

\subsubsection{Observation}

Observation is a method of collecting information about people, processes, and culture of a social setting [32]. The natural observation involves the use of human sensory systems such as eyes and ears, to acquire information which in turn requires humans to make judgements on the information gathered. Participants observation which was used in this research is the type whereby the researchers strives to an immersion in a specific aspect in order to acquire inside understanding of this aspect [33]. All lessons in the two 'Forms' regarding the study were fully observed by the researchers during the learning processes of both methods (traditional \& learner-centered). 


\subsubsection{Class quizzes}

These are simply internal written or oral examinations organized before, during or after lessons to determine the strengths and weaknesses of students. Each form was tested with four different quizzes in two batches. The first batch was pre-test on each of the two topics, before students were taken through the topics. The second batch was a post-test after the two topics were fully treated according to the syllabus, in order to assess their performance on those topics treated with the different methods (teacher-centered and learner-centered).

\subsection{Data Analysis method}

Data analysis is the process of putting facts and figures to solve the research question [34]. This may include; collecting, organizing, summarizing and interpreting the information gathered. Since the research involves both qualitative and quantitative data, the analysis of the data collected was in two ways. Qualitative data were organized and summarized by writing key ideas of respondents to keep track of what happened in the field. The researcher applied Statistical Package for Social Science (SPSS) in analyzing the quantitative data. The package is a software which was used to organize, tabulate and calculate numerical data, which were further displayed on tables. Data obtained from quizzes were the data analyzed using the Statistical Package for Social Sciences (SPSS).

\section{DATA PRESENTATION AND ANALYSIS}

This part presents the data collected from the study, which is further divided into sub-sections which presents various data according to the teaching methodology used.

\subsection{Responses of Students}

This part is in two major sections. The first part presents the findings of activities and responses of students in each 'Form' before, during, and after undertaking lessons on a new topic within their syllabus, using the traditional method of imparting knowledge. While the second part presents the findings of activities and responses of all levels before, during, and after taking lessons on a new topic each within their syllabus, using the learner-centered method of teaching.

\subsubsection{Teacher-centered approach}

This section presents the findings of activities and responses of the traditional (teacher-centered) method of imparting knowledge. The section is further divided into two parts, with each presenting the various findings of each Form.

\subsubsection{Form 1}

After reporting to school on Saturday $16^{\text {th }}$ January 2021, the first interaction with the Form 1 class with regards to the study, started Monday $18^{\text {th }}$ January 2021 between 8 am to $9 \mathrm{am}$. Statistics 1 which was the first topic to start the semester.
Day 1

Between 8am to 8:30am, the students were given a pre-class quiz of 5 theory questions which was written on the white board by the subject teacher. This was marked out of 5marks, which means each question was scored 1 mark. Questions were answered individually on answer booklets. This was purposely to test their knowledge on the topic before taking the lesson.

Below is a summary of the results obtained.

Table II: Distribution of marks scored by Form 1 students in class quiz (pretest)

\begin{tabular}{|c|c|c|c|c|c|}
\hline SN & Marks & SN & Marks & SN & Marks \\
\hline 01 & 2 & 16 & 0 & 31 & 1 \\
\hline 02 & 1 & 17 & 0 & 32 & 2 \\
\hline 03 & 1 & 18 & 0 & 33 & 0 \\
\hline 04 & 1 & 19 & 0 & 34 & 1 \\
\hline 05 & 1 & 20 & 2 & 35 & 1 \\
\hline 06 & 0 & 21 & 1 & 36 & 2 \\
\hline 07 & 0 & 22 & 3 & 37 & 2 \\
\hline 08 & 2 & 23 & 0 & 38 & 1 \\
\hline 09 & 2 & 24 & 0 & 39 & 0 \\
\hline 10 & 2 & 25 & 0 & 40 & 1 \\
\hline 11 & 2 & 26 & 1 & 41 & 2 \\
\hline 12 & 2 & 27 & 1 & 42 & 2 \\
\hline 13 & 2 & 28 & 1 & 43 & 1 \\
\hline 14 & 1 & 29 & 0 & 44 & 1 \\
\hline 15 & 1 & 30 & 2 & 45 & 1 \\
\hline
\end{tabular}

Source: Research field data, 2021

Day 2

On the second day of meeting the students between the 8:30am to 9:30am, the mathematics teacher who doubles as the Senior house mistress, introduced the topic (Statistics 1) to the students by orally stating as follows;

"statistics is the branch of mathematics which deals with the collection, presentation, and analysis of numerical data, as well as drawing conclusion the analysis made".

She further stated to the students that, statistics has become part of most branches of knowledge which includes; Biology, Business, Economics, Education, Sociology, and many more.With the students observing total silence, she (mistress) read out from her teachers' handbook, definitions and examples of some statistical terms which includes: data, frequency, class interval, class boundaries, and class midpoints. After this, students were asked by the teacher that, "what are some of the graphical tool that can be used to represent statistical data"? For about five minutes, students were silent because they have no idea. However, Pie chart, 
Bar chart, Histogram, and cumulative frequency curve were the tools mentioned to the class by the teacher.

Towards the end of the lesson, the teacher took the class through a question which states:

In a workshop, the times taken by 120 trainees to identify a fault in a machine are shown in the table below. Find the mean of the distribution.

Table III: Question.

\begin{tabular}{|c|c|c|c|c|c|c|c|c|c|c|}
\hline $\begin{array}{c}\text { Number of } \\
\text { Minutes }\end{array}$ & 1 & 2 & 3 & 4 & 5 & 6 & 7 & 8 & 9 & 10 \\
\hline $\begin{array}{c}\text { Number of } \\
\text { Trainees }\end{array}$ & 2 & 3 & 5 & 10 & 15 & 30 & 25 & 15 & 10 & 5 \\
\hline
\end{tabular}

According to her, solving for the mean from a distribution table is calculated based on the extension of the table by introducing new operations.

Solution:

Table IV: Solution to Question.

\begin{tabular}{|c|c|c|}
\hline $\begin{array}{c}\text { Number of } \\
\text { Minutes (x) }\end{array}$ & $\begin{array}{c}\text { Number of } \\
\text { Trainees (f) }\end{array}$ & $\mathrm{fx}$ \\
\hline 1 & 2 & 2 \\
\hline 2 & 3 & 6 \\
\hline 3 & 5 & 15 \\
\hline 4 & 10 & 40 \\
\hline 5 & 15 & 75 \\
\hline 6 & 30 & 180 \\
\hline 7 & 25 & 175 \\
\hline 8 & 15 & 120 \\
\hline 9 & 10 & 90 \\
\hline 10 & 5 & 50 \\
\hline & $\sum=120$ & $\sum f x=753$ \\
\hline
\end{tabular}

$$
\operatorname{Mean}(\bar{x})=\frac{\sum f x}{\sum f} \Rightarrow(\bar{x})=\frac{753}{120} \Rightarrow 6.275
$$

She explained to the students that, there could have been a follow up question which could instruct them to represent the information on any of the graphical tools treated earlier. The lesson ended about 20 minutes late due to few questions and answers that took place between the students and the teacher.

Day 3

The students wrote a class quiz of 5 marks, on what was taught so far on the topic (Statistics I).

Below are the results obtained by the 45 students who sat for the quiz (post-test).
Table V: Marks of Form 1 students in post-test quiz

\begin{tabular}{|c|c|c|c|c|c|}
\hline SN & Marks & SN & Marks & SN & Marks \\
\hline 01 & 4 & 16 & 1 & 31 & 3 \\
\hline 02 & 3 & 17 & 0 & 32 & 3 \\
\hline 03 & 2 & 18 & 2 & 33 & 3 \\
\hline 04 & 3 & 19 & 3 & 34 & 3 \\
\hline 05 & 2 & 20 & 2 & 35 & 3 \\
\hline 06 & 2 & 21 & 3 & 36 & 2 \\
\hline 07 & 2 & 22 & 3 & 37 & 2 \\
\hline 08 & 3 & 23 & 3 & 38 & 2 \\
\hline 09 & 3 & 24 & 3 & 39 & 2 \\
\hline 10 & 4 & 25 & 2 & 40 & 3 \\
\hline 11 & 3 & 26 & 2 & 41 & 3 \\
\hline 12 & 3 & 27 & 2 & 42 & 2 \\
\hline 13 & 2 & 28 & 2 & 43 & 1 \\
\hline 14 & 3 & 29 & 1 & 44 & 1 \\
\hline 15 & 1 & 30 & 4 & 45 & 1 \\
\hline
\end{tabular}

Source: Research field data, 2021.

\subsubsection{Form 2}

The 35 second year students who were part of the sample class of 80 students had their first interaction with their tutor on $21^{\text {st }}$ January 2021 , between the hours of $10 \mathrm{am}$ to $11 \mathrm{am}$.

\section{Day 1}

The students were briefed on the topic for the beginning of the term, which is Statistics II. At about 10:30am, the master gave the students a quiz of 5 questions.Few students complained silently by saying, "we are not prepared".

Below are results obtained in the quiz (pre-test).

Table VI: Marks obtained by Form 2 students in pre-test

\begin{tabular}{|c|c|c|c|c|c|c|c|c|c|}
\hline SN & Marks & SN & Marks & SN & Marks & SN & Marks & SN & Marks \\
\hline 01 & 1 & 08 & 2 & 15 & 1 & 22 & 2 & 29 & 0 \\
\hline 02 & 2 & 09 & 1 & 16 & 0 & 23 & 0 & 30 & 2 \\
\hline 03 & 0 & 10 & 2 & 17 & 0 & 24 & 1 & 31 & 1 \\
\hline 04 & 1 & 11 & 1 & 18 & 0 & 25 & 0 & 32 & 3 \\
\hline 05 & 2 & 12 & 2 & 19 & 0 & 26 & 2 & 33 & 0 \\
\hline 06 & 1 & 13 & 0 & 20 & 2 & 27 & 1 & 34 & 1 \\
\hline 07 & 1 & 14 & 1 & 21 & 1 & 28 & 1 & 35 & 1 \\
\hline
\end{tabular}

Source: Research field data, 2021.

\section{Day 2}

On the next day between the hours of 11 am to 12 noon, the master first discussed the answers of the previous quiz with students. After that, he took the students through the 
construction of a grouped frequency table, when given a raw distribution.

Below is one of the examples with solution.

Question: The weights of 30 students in a class (in $\mathrm{kg}$ ) are as follows:

\begin{tabular}{|l|l|l|l|l|l|l|l|l|l|}
\hline 42 & 52 & 46 & 63 & 47 & 40 & 50 & 63 & 52 & 57 \\
\hline 40 & 47 & 55 & 52 & 49 & 42 & 56 & 51 & 48 & 47 \\
\hline 44 & 54 & 54 & 62 & 60 & 58 & 56 & 60 & 58 & 53 \\
\hline
\end{tabular}

Construct a frequency table with class interval 5.

Solution:

Table VII: Answer to question.

\begin{tabular}{|c|c|c|c|c|c|c|}
\hline Weight $(\mathrm{kg})$ & $\begin{array}{c}40- \\
44\end{array}$ & $\begin{array}{c}45- \\
49\end{array}$ & $\begin{array}{c}50- \\
54\end{array}$ & $\begin{array}{c}55- \\
59\end{array}$ & $\begin{array}{c}60- \\
64\end{array}$ & Total \\
\hline Frequency & 5 & 6 & 8 & 6 & 5 & 30 \\
\hline
\end{tabular}

From the solution above, he further explained to students that, the solution could be represented on a histogram. In doing so however, another column should be introduced on the table which is 'class mid-points'. According to him, this is obtained by finding the average of each class.

e.g. $\frac{40+44}{2}=42$

This therefore generated another column which is represented on the horizontal axis of the histogram, while the frequency is represented on the vertical axis.

Below is a snap shot of the histogram the teacher drew on the board.

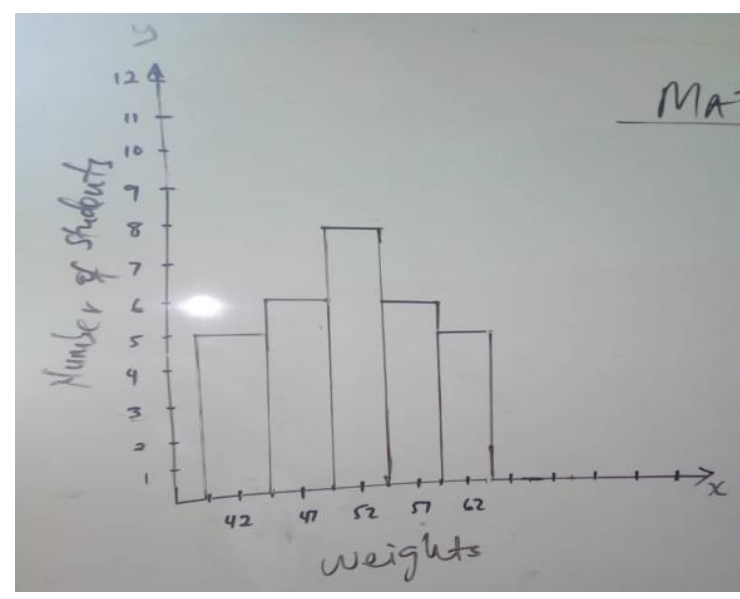

Fig 2: Snapshot of histogram

Source: Research field data, 2021.

Day 3

Students wrote a class quiz of 5 questions which were within the scope of the three-day-lessons treated. This quiz was submitted individually on answer booklets.
Below are the results obtained by the 35 students who took part in the quiz (post-test).

Table VIII: Marks obtained from Form 2 students in post-test.

\begin{tabular}{|c|c|c|c|c|c|c|c|c|c|}
\hline SN & Marks & SN & Marks & SN & Marks & SN & Marks & SN & Marks \\
\hline 01 & 3 & 08 & 3 & 15 & 2 & 22 & 2 & 29 & 3 \\
\hline 02 & 2 & 09 & 2 & 16 & 1 & 23 & 2 & 30 & 2 \\
\hline 03 & 1 & 10 & 2 & 17 & 1 & 24 & 1 & 31 & 1 \\
\hline 04 & 2 & 11 & 3 & 18 & 1 & 25 & 1 & 32 & 2 \\
\hline 05 & 2 & 12 & 2 & 19 & 2 & 26 & 2 & 33 & 0 \\
\hline 06 & 2 & 13 & 2 & 20 & 2 & 27 & 1 & 34 & 2 \\
\hline 07 & 1 & 14 & 1 & 21 & 2 & 28 & 1 & 35 & 1 \\
\hline
\end{tabular}

Source: Research field data, 2021.

\subsubsection{Student-centered approach}

This section presents the findings of activities of imparting knowledge using the student-centered approach. It is further divided into two main parts, with the first part displaying the happenings of the learning process in 'Form 1', and the second part presenting that of 'Form 2'.

\subsubsection{Form 1}

During the second week of the research in the study area, the students were taken through a different topic (Rigid motion I), with a different approach of imparting knowledge.

Day 1

Another pre-test was given to the students to test their current knowledge and understanding about the intending topic of study.

Below is a table containing the marks obtained by the students in the quiz.

Table IX: Marks obtained by Form 1 students in pre-test quiz

\begin{tabular}{|c|c|c|c|c|c|}
\hline SN & Marks & SN & Marks & SN & Marks \\
\hline 01 & 1 & 16 & 1 & 31 & 1 \\
\hline 02 & 0 & 17 & 0 & 32 & 2 \\
\hline 03 & 0 & 18 & 1 & 33 & 0 \\
\hline 04 & 1 & 19 & 0 & 34 & 2 \\
\hline 05 & 2 & 20 & 2 & 35 & 1 \\
\hline 06 & 1 & 21 & 1 & 36 & 2 \\
\hline 07 & 0 & 22 & 2 & 37 & 2 \\
\hline 08 & 2 & 23 & 0 & 38 & 1 \\
\hline 09 & 2 & 24 & 1 & 39 & 1 \\
\hline 10 & 1 & 25 & 0 & 40 & 1 \\
\hline 11 & 1 & 26 & 1 & 41 & 1 \\
\hline 12 & 1 & 27 & 1 & 42 & 2 \\
\hline 13 & 0 & 28 & 2 & 43 & 2 \\
\hline
\end{tabular}




\begin{tabular}{|l|l|l|l|l|l|}
\hline 14 & 2 & 29 & 0 & 44 & 1 \\
\hline 15 & 1 & 30 & 2 & 45 & 1 \\
\hline
\end{tabular}

Source: Research field data, 2021.

Day 2

At about 8am, the mistress met the first-year students to start another topic (Rigid motion I). The lesson began with a question from the mistress to students' which states, 'what do you understand by the term Rigid motion?' For over three minutes, no one could say a word, apart from the mistress repeating the question in a different format. She further asked another question in a story form by saying, "imagine you stand at one corner of your classroom with a ball in your hand, then you release the ball by gently throwing it to another corner. What happens to the ball? A male student in a front seat raised up his hand then answered, "the ball has moved to a different place". That's correct (the mistress said), but the shape, the size and possible the weight of the ball still remains the same (she added). This implies that, 'Rigid motion' is simply the movement of fixed bodies from one place to another without any changes in physical features. This then means the body has undergone a 'transformation'. She stated that, under 'Rigid motion I', translation and reflection of plane figures are the sections to considered.

She then grouped the students according to their sitting rows with each group containing at least 5 students, with 2 female students in each group. After that the following learning task was given to all the groups to undertake which was to be presented in the next meeting.

1) Identify and describe how an equilateral triangle of any size can be translated from one quadrant to another.

2) Identify and describe how a square with a length of $2 \mathrm{~cm}$, can be reflected to its' opposite sides using both $x$ and $y$ axes as mirrors.

After the end of the class, the students decided to stay to complete their learning tasks for the next one hour. This was undertaken through group discussions, by which almost each student shares his or her idea or opinion with regards to the issues at hand. These discussions were presided by the various group leaders, while the mistress coordinates the whole activity.

Day 3

After brushing through what was discussed in the last meeting, each group was called to present their findings through an oral and diagrammatic representation on the white board in front of the class by at least 3 members of each group within 10 minutes.

Below are the presentations of the first 3 groups for the first task.
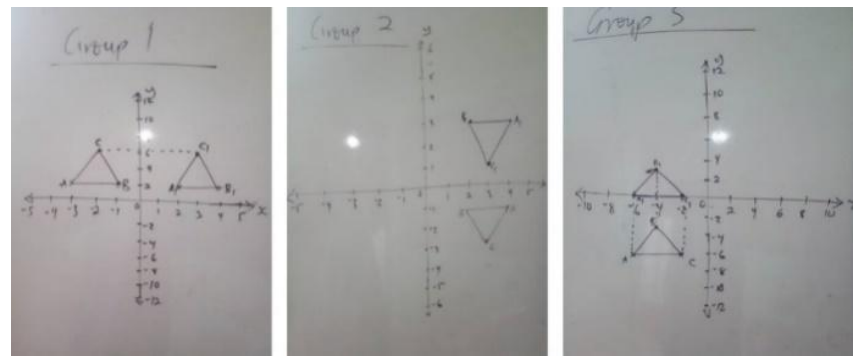

Fig. 3: Solution from Groups: 1, 2 and 3.

Source: Research field data, 2021.

Day 4

A class quiz was conducted for students to answer individually for 5 marks.

The results obtained by the students were as represented in the table below:

Table X: Marks obtained by Form 1 student in post-test.

\begin{tabular}{|c|c|c|c|c|c|}
\hline SN & Marks & SN & Marks & SN & Marks \\
\hline 01 & 3 & 16 & 2 & 31 & 4 \\
\hline 02 & 3 & 17 & 2 & 32 & 4 \\
\hline 03 & 4 & 18 & 2 & 33 & 3 \\
\hline 04 & 3 & 19 & 3 & 34 & 4 \\
\hline 05 & 3 & 20 & 5 & 35 & 4 \\
\hline 06 & 4 & 21 & 4 & 36 & 4 \\
\hline 07 & 3 & 22 & 3 & 37 & 3 \\
\hline 08 & 5 & 23 & 4 & 38 & 4 \\
\hline 09 & 4 & 24 & 3 & 39 & 4 \\
\hline 10 & 4 & 25 & 4 & 40 & 4 \\
\hline 11 & 4 & 26 & 3 & 41 & 3 \\
\hline 12 & 4 & 27 & 2 & 42 & 2 \\
\hline 13 & 3 & 28 & 4 & 43 & 2 \\
\hline 14 & 3 & 29 & 3 & 44 & 2 \\
\hline 15 & 3 & 30 & 4 & 45 & 2 \\
\hline
\end{tabular}

Source: Research field data, 2021.

\subsubsection{Form 2}

The study on the second-year students continued in the second week, with a new topic, 'Rigid motion II'. This was a continuation of the Rigid motion I which was treated last year around the same time.

\section{Day 1}

On the first day, the teacher refreshed the students' memory with questions and answers with respect to Rigid Motion I. Very few students were able to remember formulas and rules that were used in the reflection of plane figures. Then the class proceeded with a quiz of one question for 5 marks.

Below are the results obtained by the individual students. 
Table XI: Marks obtained by Form 2 students in pre-test

\begin{tabular}{|c|c|c|c|c|c|c|c|c|c|}
\hline SN & Marks & SN & Marks & SN & Marks & SN & Marks & SN & Marks \\
\hline 01 & 3 & 08 & 5 & 15 & 3 & 22 & 3 & 29 & 3 \\
\hline 02 & 3 & 09 & 4 & 16 & 2 & 23 & 4 & 30 & 4 \\
\hline 03 & 4 & 10 & 4 & 17 & 2 & 24 & 3 & 31 & 4 \\
\hline 04 & 3 & 11 & 4 & 18 & 3 & 25 & 4 & 32 & 4 \\
\hline 05 & 3 & 12 & 4 & 19 & 3 & 26 & 3 & 33 & 3 \\
\hline 06 & 4 & 13 & 3 & 20 & 5 & 27 & 2 & 34 & 4 \\
\hline 07 & 3 & 14 & 3 & 21 & 4 & 28 & 4 & 35 & 4 \\
\hline
\end{tabular}

Source: Research field data, 2021.

After the submission of the answer sheets, the teacher took the students through, on how to answer the given question correctly. After that, he gave them individual reading assignment on 'rotation of plane figures' for the next 2 days, since they were already familiar with graphical presentation of solutions.

Day 2

Students continued their personal studies on the given assignment in both daytime and night preps. Students however made consultation with other colleagues on areas they find difficulty in understanding.

Day 3

Two students were randomly selected to give a lecture on their findings on the reading assignment given. After that the teacher gave them another class quiz on the reading assignment which all students who attended the class participated on.

Results obtained were as follows:

Table XII: Marks obtained by Form 2 students in post-test

\begin{tabular}{|c|c|c|c|c|c|c|c|c|c|}
\hline SN & Marks & SN & Marks & SN & Marks & SN & Marks & SN & Marks \\
\hline 01 & 4 & 08 & 3 & 15 & 2 & 22 & 4 & 29 & 5 \\
\hline 02 & 4 & 09 & 4 & 16 & 2 & 23 & 3 & 30 & 2 \\
\hline 03 & 3 & 10 & 4 & 17 & 3 & 24 & 3 & 31 & 3 \\
\hline 04 & 4 & 11 & 5 & 18 & 2 & 25 & 4 & 32 & 4 \\
\hline 05 & 3 & 12 & 4 & 19 & 2 & 26 & 2 & 33 & 3 \\
\hline 06 & 3 & 13 & 2 & 20 & 2 & 27 & 4 & 34 & 4 \\
\hline 07 & 3 & 14 & 3 & 21 & 2 & 28 & 4 & 35 & 3 \\
\hline
\end{tabular}

Source: Research field data, 2021.

\subsubsection{Students PersonalResponses}

\subsubsection{Form 1}

The students first complained about the inactiveness of the mathematics mistress during lessons, and as result, they fill bored and sleepy especially during the first topic (Statistics I). They further complained that, most of the class quizzes came unannounced, and therefore less preparations were made.
The students shared their happiness with the approach used in treating the second topic (Rigid motion I). The group discussions according to them gave the chance for them to interact with each other, with the smart ones assisting the weak ones to be on the same pace with them. It also gave a chance for those who were shy in speaking in class, to express themselves within their groups.

\subsubsection{Form 2}

The comments of the second-year students were not very different from that of the first years for both topics treated. However, the second years were already familiar with the first part of the topics treated (Statistics I, and Rigid motion I), since both topics were treated in their first year of study. They however confirmed that, the topics to the best their knowledge were treated with their teacher been a frontline speaker with their little participation through questions and answers. Due to the previous arrangement in the first topic treated (statistics II), the foresaw another class quiz by the close of the second topic (Rigid motion II), and therefore prepared well for it. According to them, even though it was very stressful to learn something they have less knowledge on, they however realized the significance of individual learning and making good use of consultation from others, especially colleagues.

\subsection{Responses of Teachers}

According to the teachers, most students relied on the scope of the content given by their teachers and therefore do not really extend their learning to areas that are not captured by their teachers. A few serious students do study ahead with reference to their textbooks, and sometimes with consultation from the colleagues and seniors (those above their level of study). They admitted that, the teacher-centered approach enables them (teachers) to cover large portions of the syllabus within a short time. If the students' attention was almost at the same pace, it would be good approach for learning more in just a short while. However, the students are given the chance to explore much knowledge by themselves through their own techniques either collectively or individually. But this however consumes time, since weak or slow learners have to be catered for.

\subsection{Analysis and Discussions}

This part discusses the findings of the study through discussions of the various results obtained, and the information presented by the various respondents of the study.

\subsubsection{Comparison of Results}

This section shows the analysis of the findings through comparisons of the various frequencies marks scored and the mean differences of the results (pre-tests and post-tests) obtained by the students. It is further divided into three main parts, specifically the comparison of test results obtained by the students in the; traditional method, the student-centered method, and comparison of the various post-test results of the two methods. 


\subsubsection{Teacher-centered approach}

\subsection{Form 1}

The pre-test quiz which was purposely to test the previous knowledge the students possess on the intending topic of study. On the other hand, the post-test quiz was to identify the students' level of understanding based on the marks scored in the quiz after undertaking lessons on the topic of study.

Below are the tables of analysis of both test results.

Table XIII: Marks obtained by Form 1 students in Pre-test results on traditional method

\begin{tabular}{|c|c|c|c|c|}
\hline Marks & Frequency & Percent & $\begin{array}{c}\text { Valid } \\
\text { Percent }\end{array}$ & $\begin{array}{c}\text { Cumulative } \\
\text { Percent }\end{array}$ \\
\hline 0.0 & 13 & 28.9 & 28.9 & 28.9 \\
\hline 1.0 & 19 & 42.2 & 42.2 & 71.1 \\
\hline 2.0 & 12 & 26.7 & 26.7 & 97.8 \\
\hline 3.0 & 1 & 2.2 & 2.2 & 100.0 \\
\hline Total & 45 & 100.0 & 100.0 & \\
\hline
\end{tabular}

Source: SPSS, 2021.

Table XIV: Marks obtained by Form 1 students in Post-test results on traditional method

\begin{tabular}{|c|c|c|c|c|}
\hline Marks & Frequency & Percent & $\begin{array}{c}\text { Valid } \\
\text { Percent }\end{array}$ & $\begin{array}{c}\text { Cumulative } \\
\text { Percent }\end{array}$ \\
\hline 0.0 & 1 & 2.2 & 2.2 & 2.2 \\
\hline 1.0 & 5 & 11.1 & 11.1 & 13.3 \\
\hline 2.0 & 16 & 35.6 & 35.6 & 48.9 \\
\hline 3.0 & 20 & 44.4 & 44.4 & 93.3 \\
\hline 4.0 & 3 & 6.7 & 6.7 & 100.0 \\
\hline Total & 45 & 100.0 & 100.0 & \\
\hline
\end{tabular}

Source; SPSS, 2021

It is realized that from both tables that, the highest mark scored in the pre-test quiz is 3 out of 5, while in the post-test quiz, the highest mark scored is 4 out of 5 . The percentage of students who scored the lowest mark ' 0 ' in the pre-test quiz $(28.9 \%)$ has reduced in the post-test quiz to $2.2 \%$. Also, the percentage of students who scored the middle mark ' 3 ' has increased from $2.2 \%$ in the pre-test to $44.4 \%$ in the post-test. This therefore implies that, there has been improvement in the students' understanding after the interaction with the subject mistress.

\subsection{Form 2}

The second-year students also undertook a pre-test quiz and a post-test quiz also to test their previous knowledge before the start of the topic, and their level of understanding after the topic has been treated.

Below are the tables of analysis of both test results.
Table XV: Marks obtained by Form 2 students in Pre-test results on traditional method

\begin{tabular}{|c|c|c|c|c|}
\hline Marks & Frequency & Percent & $\begin{array}{c}\text { Valid } \\
\text { Percent }\end{array}$ & $\begin{array}{c}\text { Cumulative } \\
\text { Percent }\end{array}$ \\
\hline 0.0 & 10 & 28.6 & 28.6 & 28.6 \\
\hline 1.0 & 15 & 42.9 & 42.9 & 71.4 \\
\hline 2.0 & 9 & 25.7 & 25.7 & 97.1 \\
\hline 3.0 & 1 & 2.9 & 2.9 & 100.0 \\
\hline Total & 35 & 100.0 & 100.0 & \\
\hline
\end{tabular}

Source: SPSS, 2021.

Table XVI: Marks obtained by Form 2 students in Post-test results on traditional method

\begin{tabular}{|c|c|c|c|c|}
\hline Marks & Frequency & Percent & $\begin{array}{c}\text { Valid } \\
\text { Percent }\end{array}$ & $\begin{array}{c}\text { Cumulative } \\
\text { Percent }\end{array}$ \\
\hline 0.0 & 1 & 2.9 & 2.9 & 2.9 \\
\hline 1.0 & 12 & 34.3 & 34.3 & 37.1 \\
\hline 2.0 & 18 & 51.4 & 51.4 & 88.6 \\
\hline 3.0 & 4 & 11.4 & 11.4 & 100.0 \\
\hline Total & 35 & 100.0 & 100.0 & \\
\hline
\end{tabular}

Source: SPSS, 2021.

According to both results, the lowest mark scored is 0.0 which was scored by 10 students in the pre-test quiz representing a total percentage of $28.6 \%$, while 1 student scored it in the post-test quiz to represent $2.9 \%$. for the 'Marks' 2 and 3, there is an increase in the total number of students scored from 9 to 18, and from 1 to 4 respectively. This therefore means that there has been a slight improvement in the students' performance after the topic was treated.

\subsubsection{Student-centered approach}

This part compares the results of the pre-test and post-test quizzes of both 'Forms', before and after the various topics were treated, through group discussions and individualized learning.

\subsection{Form 1}

This part compares the pre-test results and post-test results of the students before and after the topic was treated. The pretest quiz was based on the students own or previous understanding of the topic before it was treated. The post-test quiz was taken after the topic was completed.

Below are the tables of results obtained by the students in both quizzes.

Table XVII: Marks obtained by Form 1 students in Pre-test results on studentcentered method

\begin{tabular}{|c|c|c|c|c|}
\hline Marks & Frequency & Percent & $\begin{array}{c}\text { Valid } \\
\text { Percent }\end{array}$ & $\begin{array}{c}\text { Cumulative } \\
\text { Percent }\end{array}$ \\
\hline 0.0 & 10 & 22.2 & 22.2 & 22.2 \\
\hline
\end{tabular}




\begin{tabular}{|c|c|c|c|c|}
\hline 1.0 & 21 & 46.7 & 46.7 & 68.9 \\
\hline 2.0 & 14 & 31.1 & 31.1 & 100.0 \\
\hline Total & 45 & 100.0 & 100.0 & \\
\hline
\end{tabular}

Source: SPSS, 2021.

Table XVIII: Marks obtained by Form 1 students in Post-test results on student-centered method

\begin{tabular}{|c|c|c|c|c|}
\hline Marks & Frequency & Percent & $\begin{array}{c}\text { Valid } \\
\text { Percent }\end{array}$ & $\begin{array}{c}\text { Cumulative } \\
\text { Percent }\end{array}$ \\
\hline 2.0 & 7 & 15.6 & 15.6 & 15.6 \\
\hline 3.0 & 17 & 37.8 & 37.8 & 53.3 \\
\hline 4.0 & 19 & 42.2 & 42.2 & 95.6 \\
\hline 5.0 & 2 & 4.4 & 4.4 & 100.0 \\
\hline Total & 45 & 100.0 & 100.0 & \\
\hline
\end{tabular}

Source: SPSS, 2021.

According to the pre-test results, the lowest mark scored is 0.0 by 10 students representing a total percentage of $22.2 \%$, while in the post-test results, the lowest mark is 2.0 which was actually the highest mark obtained in the pre-test. 7 students scored 2.0 in the post-test which represents a percentage of $15.6 \%$. Also, 2 students scored the highest mark of 5 in the post test which represents $4.4 \%$ of the total students score. This therefore means that, there was significant improvement in the students' level of understanding after the topic was treated, since the lowest mark raised from 0.0 to 2.0, highest mark scored also increased from 2.0 to 5.0 with respect to both quizzes.

\subsection{Form 2}

Pre-test results and post-test results obtained from the second years before and after the study of the topic through discussion and individualized learning among students are compared.

Below are the tables of results of the pre-test and post-test results.

Table XIX: Marks obtained by Form 2 students in Pre-test results on studentcentered method

\begin{tabular}{|c|c|c|c|c|}
\hline Marks & Frequency & Percent & $\begin{array}{c}\text { Valid } \\
\text { Percent }\end{array}$ & $\begin{array}{c}\text { Cumulative } \\
\text { Percent }\end{array}$ \\
\hline 0.0 & 4 & 11.4 & 11.4 & 11.4 \\
\hline 1.0 & 9 & 25.7 & 25.7 & 37.1 \\
\hline 2.0 & 19 & 54.3 & 54.3 & 91.4 \\
\hline 3.0 & 3 & 8.6 & 8.6 & 100.0 \\
\hline Total & 35 & 100.0 & 100.0 & \\
\hline
\end{tabular}

Source: SPSS, 2021.

Table XX: Marks obtained by Form 2 students in Post-test results on studentcentered method

\begin{tabular}{|c|c|c|c|c|}
\hline Marks & Frequency & Percent & $\begin{array}{c}\text { Valid } \\
\text { Percent }\end{array}$ & $\begin{array}{c}\text { Cumulative } \\
\text { Percent }\end{array}$ \\
\hline 2.0 & 9 & 25.7 & 25.7 & 25.7 \\
\hline
\end{tabular}

\begin{tabular}{|c|c|c|c|c|}
\hline 3.0 & 12 & 34.3 & 34.3 & 60.0 \\
\hline 4.0 & 12 & 34.3 & 34.3 & 94.3 \\
\hline 5.0 & 2 & 5.7 & 5.7 & 100.0 \\
\hline Total & 35 & 100.0 & 100.0 & \\
\hline
\end{tabular}

Source: SPSS, 2021.

From both tables, it's seen that there has been an increase in the lowest mark scored, from 0.0 in the pre-test to 2.0 in the post-test results. The highest mark scored has also increased from 3.0 in the pre-test to 5.0 in the post-test results. Considering the 'Mark 3.0' in both test results, it's seen that, 3 students scored 3.0 to represent $8.6 \%$ of total score in the pretest, while 12 students representing $34.3 \%$ in the post-test scored the same mark.This may therefore imply that, there has been great improvement in performance of the students after the lessons.

\subsubsection{Post test results}

This part compares the post-test results of each 'Form' in both method of imparting knowledge (traditional and studentcentered), in other to assess the performance after lesson of both methods.

\section{Form 1}

Comparing the post-test results obtained by the students after the traditional method (table) of teaching and the studentcentered method of teaching (table), it shows that, there have been significant Improvement in the test results after the student-centered approach was used. It is realized that, the lowest mark scored in the test after using the traditional method was 0.0, while the lowers Mark scored after the student-centered method was 2.0. also, the highest Mark scored during the traditional method was 3.0, while that of the student-centered method was 5.0. according to the various results, the 'Mean Mark' for the post-test results in the traditional method is ' $\bar{X}=2.4222$ ', while that of the studentcentered method is $\bar{X}=3.3560^{\prime}$ '. This therefore implies that, the student-centered method used during the study has tremendously enhanced improvement of the first-year students.

\section{Form 2}

The second years' post-test results could also be compared using the lowest and highest 'Marks' scored, as well as their various 'Mean Marks'. From tables, the lowest and highest marks scored by the class after undertaking the traditional method of teaching are 0.0 and 3.0, while those marks they obtained after undertaking the student-centered method of teaching are 2.0 and 5.0. Also, the various 'Mean marks' obtained from both results are 1.7140 and 3.2000. It is therefore seen clearly that, the students performed well after being exposed to the student-centered method of studying.

\section{SUMMARY, CONCLUSIONS AND RECOMMENDATIONS}


This part presents the summary of findings of collected and analyzed data, conclusions drawn out of the findings, and recommendations. It is divided into three sections, where section 5.1 presents the summary of findings, section 5.2 presents the conclusions drawn out of the findings, and section 5.3 presents the recommendations suggested by the researcher after the study.

\subsection{Summary of Findings}

\subsubsection{Teachers}

From the demographic profile of the teachers, it is realized that, they all possess the minimum qualification that qualifies them to teach in second cycle institutions. About 3 of the teachers have attained a higher level of education (masters'), which is evident that, they have had higher training in imparting knowledge. Also, the minimum length of time spent in the service by the teachers is not less than 5 years, which implies that, the teachers are experienced in the work.

According to ourobservation, all the teachers were always available and punctual to the meetings with the researcher and as well with the students, which implies that, their contribution to the study was effective.

\subsubsection{Students}

As indicated in the previous chapters, the final year students (Form 3) could not take part in the study due to their preparations towards their intending 'Mock Examination', and as a result, only the first- and second-year students took part. Students participation, especially the female students, was encouraging as they managed to take part in all the lessons for the purpose of the research. All students also participated in the quizzes conducted during the research period, which enhanced a suitable analysis of the results obtained. This therefore implies that, the students also contributed effectively towards the study.

\subsubsection{Results obtained}

From the comparisons of the results obtained from the students in the previous chapter, it is clear that there is always an improvement in the performance of the students after lessons have been undertaken by the guidance of their teacher. Irrespective of the methodology used during the lessons, the marks scored by the students after undertaking lessons are always far better than those obtained before the lessons. However, the results between the two methodologies used in delivering the lessons (traditional and student-centered) shows that, students perform better when the student-centered method is used in both 'Forms' ( 1 and 2). Given the students the opportunity to learn on their own, and from themselves could be considered as good methodology to impart or share knowledge with them and/or among them.

\subsection{Conclusion}

Based on the overall findings of the study, the following conclusions were drawn by the researcher with respect to the two methods of teaching:

\subsubsection{Teacher-centered}

For this method of imparting knowledge, it can be concluded that:

i. The teacher is the overall source of knowledge as he gives out what is to be learnt, the extend and depth of the studies as well as the method to use and systematic format of the learning processes. In most of the lessons during this method, the teacher is always the one who does most of the talking under the watch of the students. Students' contribution to the learning process is therefore very low, which results in low understanding and low performance especially among the slow learners.

ii. A lot of knowledge is covered within a short period of time, since the knowledge comes from one person who does most of the talking, writing and demonstration. For those who were being introduced to new knowledge (unknown or untreated topics) during the study, a whole topic was covered within a couple of days of meeting. This could be an advantage to smart students, as more, if not all of the, topics in the syllabus could be covered within the expected duration.

iii. Teachers have greater control over the class during the lessons using this method of teaching, as more students pay attention to what he/she is delivering to them. As students might not get the chance to share ideas that are beyond the scope of what is been thought during the lessons, it gives the teacher the opportunity to stay focused within the aspect that is been planned to cover.

\subsubsection{Student-centered}

It can be concluded from the study that:

i. The pace and depth to which the students acquire knowledge is on their own hands, only with the supervision of the teacher. Students are either put in groups to collaborate in undertaking learning task through group discussions and/ or individual contributions. Students are able to understand better from their own learning since they have control over what they do, as well as learning from the colleagues through basic questioning and answering between them.

ii. A lot of knowledge were not covered as expected since slow or weak learners at some point seems to destruct the smart ones, in other for all students to be at the same pace. This sometimes bores the smart students, and might eventually discourage them from group learning.

iii. Students were able to develop self-confidence since it was mandatory for them to contribute towards the accomplishment of the given tasks. Most students who 
find it difficult to contribute or express themselves in whole class discussion were able to share their thoughts and ideas with their group members due to its' (group) small nature. Those who took part in the presentations were also exposed to playing the role of the teacher at some point.

\subsubsection{Compared results}

From the study, it could be concluded that, the studentcentered method of teaching has heightened the performance of the students as compared to that of the traditional method. As seen in the previous chapter, the is a great significant difference between the results obtained from the same students after undertaking two different methods of imparting knowledge. Though they might be some other factors that might have contributed to those results, the study could not take notice of those factors as well as assessing them.

\subsection{Recommendations}

\subsubsection{Mathematics Teachers}

The researchersrecommend that; teachers should consider the following;

i. The students' individual intellectual level in all sections of the learning process, from the planning stage to the point of executing the lessons and assessments. There is no doubt that students at the same level of study possess different intelligent quotients (IQs), mean while they're all supposed to learn the same thing, at the same time, at the same place, and from the same person. Mixed methods of teaching which includes lecture method, group work activities, and individualized learning among others should be considered in the learning process. There could be separate mode of assessment for slow/weak students and that of smart students. This would provide a suitable platform to monitor the progress being made in both categories of students in their learning.

ii. Upgrade their knowledge in teaching methodologies by undertaking professional courses as well taking in-services trainings and workshops to which would help heightened their knowledge and experience. This would enable them to identify and use methods that will enable effective and efficient teaching and learning.

\subsubsection{Students}

The researchers recommend the following for students to consider:

i. They should at all times try to take part in all academic activities, especially during lessons with their teacher or group activities with their colleagues. Practically, most students especially truant ones, feel reluctant to participate in academic activities even when present during those moments. This could sometimes be attributed to laziness or lack of concentration due to what is been thought or how is been thought. With them (students) paying keen attention through most of the learning process, they would at least gain some level of understanding, especially from the contributions of their colleagues.

ii. They should as well learn beyond the scope of what is been introduced in the class during lessons. Due to time and capacity constraints, all sections of the syllabus cannot be completed through the usual class interactions. With the aid of library and other academic facilities, students should do more research either in groups or individually in order to cover other significant parts of the syllabus, as well as gain more knowledge beyond those provided by their teachers or colleague students.

\subsubsection{School Administration}

The study recommends the following to school administration:

i. For purposes of academic work and increase in enrolment due to the 'Free Educational Policy', school administration should improve on academic facilities such as libraries and laboratories. Academic materials such as books, newspapers, journals, laboratory apparatus, tools and equipment, and internet facilities should be made available to facilitate academic work. This could therefore enhance effective teaching and learning, as well as improving students' performance.

ii. They should invest on teachers' professional skills by organizing seminars, workshops and in-service training for teachers in order to assist them to build on existing ideas as well as discover new ones to facilitate their teaching. Teachers who steaks to old techniques would have the opportunity to learn for themselves and understand the need to apply diverse methods of techniques in teaching. For instance, training teachers on how to use mathematics software programs in setting exam questions.

\subsection{Future research}

A similar study be undertaken in other subject areas, especially both core subjects and elective subjects of all the programs of study within the senior high school level in Ghana. With this, it could also be undertaken in other schools in other districts within the country. This could assist in justifying the findings of this study.

\section{REFERENCES}

[1] Abdulbaki, K., Suhaimi, M., Alsaqqaf, A.,\& Jawad W. (2018). Impact of using the lecture method on teaching English at university. Eur J Educ Stud 4(5):285 - 302. https://files.eric.ed.gov/fulltext/EJ1200403.pdf 
[2] Afurob, A., Izuagba, A., and Ifegbo, P. (2015). Effects of the Use Lecture Method and Wordle on the Performance of Students Taught Curriculum studies 1: EDU 222. Journal of Education and Practice, $\quad 6(18), \quad 142 \quad-149$. https://files.eric.ed.gov/fulltext/EJ1079790.pdf

[3] Agwu Udu, D. 2018. Comparative Effects of Individualised and Cooperative Learning Instructional Strategies on Senior Secondary School Students' Academic Achievement in Organic Chemistry. Electronic Journal of Science Education, 22(2), 1-14.

[4] Amoah, S.A, and Eshun, S. (2015). Research methods, Winneba: Institute of Educational Development Extension, University of Education.

[5] Antwi, V., Opare, S.A., Fianoo, G.A., Manu, F.O., and Danquah, J. (2019). Assessing Learner-Centred Approach and Teaching and Learning Materials in Physics Lessons in the Colleges of Education in Ghana. International Journal of Modern Physics and Applications. Vol. 5, No. 2, 2019, pp. 17-25.

[6] Ashirwadam, J. (2014). Methods of Data Analysis. https://www.academia.edu/8135057/Methods_of_Data_Analysis.

[7] Baeten, M., Kyndt, E., Struyven, K. \&Dochy, F. (2010). Using student-centered learning environments to stimulate deep approaches to learning: Factors encouraging or discouraging their effectiveness. Educational Research Review. 5. 243-260. 10.1016/j.edurev.2010.06.001.

[8] Barraket, J. (2005). "Teaching Research Method Using StudentCentered Approach? Critical Reflections on Practice." Journal of University Teaching and Learning Practice 2 (2).

[9] Bethell, G. (2016). Assessment of mathematics in sub-Sahara Africa: Status, challenges, and opportunities. Washington D.C: Cambridge Education/World Bank.

[10] Bingolbali, E. and Bingolbali, F. (2015). Principles of studentcentered teaching and implications for mathematics teaching. CERME 9 - Ninth Congress of the European Society for Research in Mathematics Education, Charles University in Prague, Faculty of Education; ERME, Feb 2015, Prague, Czech Republic. pp.2600-2606. ffhal-01289421f

[11] Blumberg, P., (2008). Developing Learner Centered Teaching: A practical guide for faculty. San Francisco: Jossey-Bass.

[12] Bose, A., and Jehan, M. (2018). Impact of "Group Discussion" As A Teaching-Learning Method On Performance of Poor Performers in The Subject of Anatomy.

[13] Bretschneider, P. J., Cirilli, S., Jones, T., Lynch, S., \& Wilson, N. A. (2017). Document Review as a Qualitative Research Data Collection Method for Teacher Research.

[14] Churchur, K. A., Asiedu-Owuba, L. and Adjabui, M. (2015). Assessment of students' performance in mathematics at the second cycle schools in the Kassena-Nankana municipality. Global Educational Research Journal: ISSN-2360-7963, Vol. 3(1): pp 247-257

[15] Ciesielska, M., \&Jemielniak, D. (2018). Qualitative Methodologies in Organization Studies Volume II: Methods and Possibilities.

[16] Creswell, J.W. (2008). Educational research: Planning, conducting, and evaluating quantitative and qualitative research. Upper Saddle River, NJ: Pearson/Merrill Education.

[17] Current issues in mathematics education https://www.comap.com/Free/C_I_IN_MAT_ED/PDF/CURRENT _ISSUES_IN_MAT_EDUCATION.pdf

[18] Darsih, E. (2018). Learner-centered learning: What makes it effective. Indonesian EFL Journal, 4(1), 33-42.DOI:10.25134/ieflj. v4i1.796.

[19] Davis, K.E., Ampadu, E., \&Carr, M.E. (2019). Valuing in Mathematics Learning Amongst Ghanaian Students: What Does It Look Like Across Grade Levels? DOI: 10.1007/978-3-030-168926 6.

[20] Ernst, H. (2014). Assessment for Learning in Secondary Mathematics. https://www.researchgate.net/publication/270822789_ASSESSME NT_FOR_LEARNING_IN_SECONDARY_MATHEMATICS
[21] Gningue, S.M., Peach, R., and Schroder, B. (2013) "Developing Effective Mathematics Teaching: Assessing Content and Pedagogical Knowledge, Student-Centered Teaching, and Student Engagement," The Mathematics Enthusiast: Vol. 10: No. 3, Article 6.

[22] Hein, G. E. (1991). Constructivist learning theory. Paper presented at the ICOM CECA Conference: The Museum and the Needs of People, Jerusalem.

[23] HERD. (2016). Focus group discussion. https://www.herd.org.np/uploads/frontend/Publications/Publicatio nsAttachments 1/1485497050Focus\%20Group\%20Discussion_0.pdf

[24] Karp, A. (2017). Current Issues in Mathematics Education; Materials of the American-Russian Workshop. Retrieved from: https://www.comap.com/Free/C_I_IN_MAT_ED/PDF/CURRENT _ISSUES_IN_MAT_EDUCATION.pdf

[25] Kawishe, T.K. (2016). Implementation of learner-centred methods within the constraints of shortage of instructional resources and facilities: A case of Itigi district council. (Master thesis, Mzumbe University, Tanzania).

[26] Kawulich, B. (2012). Collecting data through observation. https://www.researchgate.net/publication/257944783_Collecting_ data_through_observation.

[27] McCombes, S. (2019). Understanding different sampling methods. https://www.scribbr.com/methodology/sampling-methods.

[28] Melor, F. (2014). Effectiveness of Student-Centered Approach to Improve Mathematics Achievement among Primary 4 Students. (Bachelor thesis, UniversitiTeknologi Mara, Malaysia).

[29] Mensah, S.K.E, and Attah-Boison, G.K. (2015). General Methods, Techniques and Skills of Teaching.

[30] Mereku, D. K. (2010). Five decades of school mathematics in Ghana. Mathematics Connections, 9(8), 73-86.

[31] Ministry of Education. (2010). Teaching syllabus for Core Mathematics (Senior High School). https://mingycomputersgh.files.wordpress.com/2015/03/coremaths-syllabus2.pdf

[32] Nyumba, T., Wilson, K., Derrick, C.J., and Mukherjee, N. (2018). The use of focus group discussion methodology: insights from two decades of application in conservation. Methods EcolEvol 9(1):20-32.

[33] Okotubu, J. O. (2020). Effect of Demonstration Teaching Method on Students' Academic Achievement and Retention in Auto Mechanics Trade in Technical Colleges in Delta State.Vol. 6, no.5, $\quad$ pp. $\quad 6 \quad-$ https://iiardpub.org/get/JJEE/VOL.\%206\%20NO.\%205\%202020/ Effect\%20of\%20Demonstration\%20Teaching.pdf

[34] Omair, A. (2014). Sample size estimation and sampling techniques for selecting a representative sample. Saudi Commission Journal of Health Specialties. 2. 142-147. 10.4103/1658-600X.142783.

[35] Phrasisombath, K. (2009). Sample Size and Sampling Methods (Vientiane: University of Health Sciences) https://www.gfmer.ch/Activites_internationales_Fr/Laos/PDF/Sam ple_size_methods_Phrasisombath_Laos_2009.

[36] Pijls, M., and Dekker, R. (2011). Students discussing their mathematical ideas: the role of the teacher. Math Ed Res J 23, 379-396 (2011). https://doi.org/10.1007/s13394-011-0022-3

[37] Saragih, S. and Napitupulu, E. (2015). Developing StudentCentered Learning Model to Improve High Order Mathematical Thinking Ability. International Education Studies. 8. 10.5539/ies.v8n6p104.

[38] Singh, A. S, and Masuku, M. B. (2014). "Sampling techniques \& determination of sample size in applied statistics research: an overview," International Journal of Economics, Commerce and Management, vol. 2, no. 11, pp. 1-22, 2014.http://ijecm.co.uk/wpcontent/uploads/2014/11/21131.pdf

[39] Stokes, K. (2013). The impact of the factory Model of education in central Texas. Texas. Baylor University.

[40] Talbert, E. (2017). Student-Centered Instruction and its effect on Mathematics Engagement by Race. (Bachelor thesis, University of 
International Journal of Research and Innovation in Social Science (IJRISS) |Volume VI, Issue I, January 2022 |ISSN 2454-6186

Pittsburgh, USA). http://d-

scholarship.pitt.edu/30641/1/ETD_Finalversion.pdf
[41] World Bank. (2016). Mathematics education in Sub-Saharan Africa: status, challenges, and opportunities (Vol. 2): main report (English). Washington, D.C.: World Bank Group. 